\title{
Proces wygaszania kapitałowej części ubezpieczenia emerytalnego
}

\author{
Autor: Sebastian Jakubowski
}

\begin{abstract}
Abstrakt
Opracowanie omawia skutki reformy emerytalnej z 2014 r. dla kapitałowej części drugiego filaru systemu emerytalnego. Analiza skupia się na skutkach znaczącego obniżenia składek przekazywanych do OFE, wprowadzenia swoistej dobrowolności ich opłacania oraz implikacjach funkcjonowania tzw. suwaka bezpieczeństwa, a także jednorazowego transferu środków z otwartych funduszy emerytalnych do ZUS. Główną tezą niniejszego artykułu jest stwierdzenie, że wprowadzone w 2014 roku zmiany prowadzą do stopniowego i nieformalnego wygaszania kapitałowej części ubezpieczenia emerytalnego. Czynnikiem decydującym o dalszym rozwoju rynku otwartych funduszy emerytalnych będzie wyrok w sprawie zasad wypłat emerytur ze środków zgromadzonych w otwartych funduszach emerytalnych. Zastosowana w opracowaniu metoda badawcza to ekonomiczna analiza prawa.
\end{abstract}

Słowa kluczowe: OFE, fundusz emerytalny, drugi filar, system emerytalny, wypłata emerytur

JEL: J32, J26

\section{Wstęp}

Od powstania otwartych funduszy emerytalnych minęło już ponad 15 lat. Przez ten stosunkowo krótki, jak na funkcjonowanie powszechnego systemu emerytalnego, czas ujawnił się szereg niedoskonałości i błędów konstrukcyjnych w systemie OFE. Niedoskonałości te, jak również kryzys finansowy, pogarszający się stan finansów publicznych oraz niezadowalające
Historia: otrzymano 2015-09-23, poprawiono 2015-11-21, zaakceptowano 2015-11-21

członków zyski OFE doprowadziły do poważnych zmian $w$ ramach drugiego filaru systemu emerytalnego. Pierwsza reforma kapitałowej części ubezpieczenia emerytalnego przeprowadzona została w 2011 r., a kolejna niedługo później, bo już na przełomie 2013 i 2014 r. Skutkiem tych reform jest między innymi znaczące obniżenie składek na otwarte fundusze emerytalne, wprowadzenie swoistej dobrowolności ich opłacania oraz transfer 
Tabela 1. Planowany oraz ostateczny podział drugofilarowej składki między OFE i subkonto w ZUS (procent podstawy wymiaru)

\begin{tabular}{|c|c|c|c|c|c|c|c|c|}
\hline Rok & $\mathbf{2 0 1 0}$ & $\mathbf{2 0 1 1}$ & $\mathbf{2 0 1 2}$ & $\mathbf{2 0 1 3}$ & $\mathbf{2 0 1 4}$ & $\mathbf{2 0 1 5}$ & $\mathbf{2 0 1 6}$ & $\begin{array}{c}\text { Ostateczny podział } \\
\text { po 1 lutego 2014 }\end{array}$ \\
\hline OFE & $7,3 \%$ & $2,3 \%$ & $2,3 \%$ & $2,8 \%$ & $3,1 \%$ & $3,3 \%$ & $3,5 \%$ & $2,92 \%$ \\
\hline $\begin{array}{c}\text { Subkon- } \\
\text { to w ZUS }\end{array}$ & $0 \%$ & $5,0 \%$ & $5,0 \%$ & $4,5 \%$ & $4,2 \%$ & $4,0 \%$ & $4,0 \%$ & $4,38 \%$ \\
\hline
\end{tabular}

Źródło: opracowanie własne na podstawie art. 21 w związku z art. 22 ustawy nowelizującej z 2011 r. oraz art. 22 ust. 3 ustawy o s.u.s.

środków z otwartych funduszy emerytalnych do ZUS. Warto przeanalizować, jakie są konsekwencje tych zmian dla dalszego istnienia rynku otwartych funduszy emerytalnych. Problemem badawczym niniejszego opracowania jest pytanie, czy zmiany te mogą prowadzić do stopniowego i nieformalnego wygaszania kapitałowej części ubezpieczenia emerytalnego. Przy czym należy podkreślić, że czynnikiem decydującym o dalszym rozwoju rynku OFE będzie wyrok Trybunału Konstytucyjnego w sprawie zasad wypłat emerytur ze środków zgromadzonych w otwartych funduszach emerytalnych.

\section{Obniżenie składek przekazywanych do OFE}

niezadowalające wyniki funduszy emerytalnych oraz pogłębiające się problemy fiskalne państwa polskiego wymusiły przeprowadzenie pierwszej reformy drugiego filaru systemu emerytalnego w maju 2011 r. Jej kluczowymi elementami było podzielenie składki przekazywanej do OFE i przekierowanie jej części do nowo utworzonych subkont w ZUS (Dz. U. z 2011 r., nr 75, poz. 398, cyt. dalej: ustawa nowelizująca z 2011 r.). Zgodnie z art. 21 w związku z art. 22 ustawy nowelizującej z 2011 r., w brzmieniu przed 1 lutego 2014 r., dotychczasowa składka trafiająca do OFE w wysokości 7,3\% podstawy wymiaru została podzielona na część nadal trafiającą do OFE w wysokości $2,3 \%$ podstawy wymiaru oraz część w wysokości 5\% podstawy wymiaru, która zaczęła trafiać na nowo utworzone w ramach drugiego filaru subkonta w ZUS ${ }^{1}$. Proporcje te miały ulegać zmianie na korzyść składki na OFE w kolejnych latach (tab. 1). Ostatecznie ustawa o zmianie niektórych ustaw w związku z określeniem zasad wypłaty emerytur ze środków zgromadzonych w otwartych funduszach emerytalnych ustaliła ten podział na poziomie 2,92\% podstawy wymiaru - składka na OFE oraz 4,38\% podstawy wymiaru - składka na subkonto w ZUS (Dz. U. z 2013 r., poz. 1717., cyt. dalej: ustawa nowelizująca z 2013 r.). Podział ten jak dotąd nadal jest aktualny i obecnie brakuje planów co do zmiany tych proporcji (Dz. U. z 2009 r., nr 205, poz. 1585 ze zm., cyt. dalej: ustawa s.u.s.).

Środki trafiające na subkonto w ZUS są wykorzystywane do finansowania bieżących świadczeń emerytalnych. Paradoksalnie więc w ramach kapitałowego filaru ubezpieczenia emerytalnego stosowana jest metoda repartycyjna. Środki wpłacane na subkonto w ZUS są tylko ewidencjonowane i nie są one w jakikolwiek

$\overline{1}$ O kontrowersjach związanych $\mathrm{z}$ utworzeniem instytucji subkonta pisał Kamil Antonów (Antonów 2011: 348), oraz Radosław Pacud (Pacud 2012: 17-32). 
Tabela 2. Najmłodsi członkowie otwartych funduszy emerytalnych wg wieku (stan na koniec wybranego kwartału)

\begin{tabular}{|c|c|c|c|}
\hline \multicolumn{4}{|c|}{ Członkowie otwartych funduszy emerytalnych wg wieku } \\
\hline Data & 17 lat i mniej & $\mathbf{1 8 - 2 0}$ & $\mathbf{2 1 - 2 5}$ \\
\hline VI 2011 & 32185 & 252606 & 1779056 \\
\hline XII 2011 & 17535 & 176275 & 1545069 \\
\hline VI 2012 & 24192 & 220150 & 1675958 \\
\hline XII 2012 & 40406 & 270366 & 1780013 \\
\hline VI 2013 & 34694 & 226643 & 1590108 \\
\hline XII 2013 & 37964 & 255710 & 1697005 \\
\hline VI 2014 & 34786 & 223553 & 1529801 \\
\hline XII 2014 & 34782 & 223663 & 1530775 \\
\hline III 2015 & 1167 & 149165 & 1215886 \\
\hline
\end{tabular}

Źródło: opracowanie własne na podstawie „Biuletynów Kwartalnych KNF - Rynek OFE”

sposób gromadzone i inwestowane (Klimkiewicz 2013). Ewidencjonowanie składek następuje niezwłocznie, nie później jednak niż w ciągu 15 dni roboczych przy użyciu dokumentów płatniczych, raportów miesięcznych lub deklaracji (art. 40a ust. 2 ustawy o s.u.s.). Ewidencjonowane składki podlegają corocznej waloryzacji według średniego nominalnego wzrostu PKB z ubiegłych 5 lat (art. 40c ust. 4 ustawy o s.u.s.). Przy czym w wyniku przeprowadzonej waloryzacji stan subkonta nie może ulec obniżeniu (art. 40c ust. 1 ustawy o s.u.s.). Oznacza to, że wyeliminowano możliwość ponoszenia nominalnych strat przez ubezpieczonego (Zawieja-Żurowska 2013). Termin waloryzacji składek na subkoncie jest zbieżny z terminem waloryzacji składek zewidencjonowanych na koncie ubezpieczonego $\mathrm{w}$ ramach pierwszego filaru systemu ubezpieczenia emerytalnego.

Wprowadzenie subkonta w ZUS i rozbicie drugofilarowej składki na dwie części (oznaczające obniżenie składki na OFE) było pierwszym elementem ograniczającym napływ środków do otwartych funduszy emerytalnych (Marcinkiewicz 2011: 16-18). Już od tego momentu można zauważyć spadek wielkości kwot przekazywanych przez ZUS do funduszy w ramach składki. O ile kwota składek przekazanych przez ZUS do OFE w pierwszym kwartale 2011 r. wyniosła prawie 6,5 mld zł, o tyle w trzecim kwartale tego samego roku było to już tylko 2,2 mld zł, a w czwartym nawet poniżej 2 mld zł (tab. 4). Spadek ten został częściowo nadrobiony w wyniku podniesienia składki trafiającej do OFE z 2,3\% do $2,8 \%$ podstawy wymiaru na początku 2013 r. Dzięki temu kwota składek trafiających do OFE wzrosła z 2,2 mld zł w czwartym kwartale 2012 roku do prawie 4 mld zł w trzecim kwartale 2013 roku (tab. 4).

\section{Dobrowolność przekazywania składek do OFE}

Kolejnym elementem, który przyczynił się do znaczącego spadku dodatnich przepływów pieniężnych do OFE 
Tabela 3. Całkowita liczba członków OFE w ostatnich 10 latach (stan na koniec wybranego półrocza)

\begin{tabular}{|c|c|}
\hline Data & Liczba członków OFE \\
\hline VI 2005 & 11414121 \\
\hline XII 2005 & 11720737 \\
\hline VI 2006 & 11990198 \\
\hline XII 2006 & 12353327 \\
\hline VI 2007 & 12718185 \\
\hline XII 2007 & 13134081 \\
\hline VI 2008 & 13502000 \\
\hline XII 2008 & 13823806 \\
\hline VI 2009 & 14111304 \\
\hline XII 2009 & 14360664 \\
\hline VI 2010 & 14612907 \\
\hline XII 2010 & 14930991 \\
\hline VI 2011 & 15279980 \\
\hline XII 2011 & 15493373 \\
\hline VI 2012 & 15735064 \\
\hline XII 2012 & 15942282 \\
\hline VI 2013 & 16209162 \\
\hline XII 2013 & 16377714 \\
\hline VI 2014 & 16679718 \\
\hline XII 2014 & 16621686 \\
\hline VI 2015 & 16583383 \\
\hline
\end{tabular}

Źródło: opracowanie własne na podstawie „Biuletynów Kwartalnych KNF - Rynek OFE”

z tytułu składek emerytalnych, było wprowadzenie w 2014 r. swoistej dobrowolności korzystania z usług OFE dla najmłodszych osób. Obecnie osoby, które dopiero wkraczają na rynek pracy i nie zostały wcześniej członkami OFE, mają realny wybór co do tego, czy w ramach drugiego filaru emerytalnego odprowadzać składkę tylko na subkonto w ZUS (7,3\% podstawy wymiaru), czy też jednocześnie odprowadzać ją na subkonto w ZUS (4,38\% podstawy wymiaru) i do wybranego przez ubezpieczonego OFE $(2,92 \%$ podstawy wymiaru) (art. 39 ust. 1 ustawy o s.u.s.). Już obecnie skutkuje to spadkiem liczby członków w tej kategorii wiekowej (tab. 2).

Najbardziej widoczny jest spadek w najmłodszej kategorii wiekowej, tj. osób poniżej 18 roku życia. W ciągu pierwszego kwartału 2015 roku liczba najmłodszych członków OFE spadła trzydziestokrotnie - z prawie 35 tys. osób do zaledwie 1167 osób. W kolejnych kategoriach wiekowych spadek nie był tak spektakularny, ale w ujęciu absolutnym jeszcze większy. 
Tabela 4. Wysokość składek przekazanych w danym kwartale przez ZUS do OFE (PLN)

\begin{tabular}{|c|c|}
\hline Data & $\begin{array}{l}\text { Kwota składek } \\
\text { przekazanych w danym } \\
\text { kwartale (PLN) }\end{array}$ \\
\hline $20091 \mathrm{kw}$ & 5015746293,57 \\
\hline $20092 k w$ & 5811904205,82 \\
\hline $20093 \mathrm{kw}$ & 5515051970,18 \\
\hline 2009 4kw & 5175470007,28 \\
\hline $20101 \mathrm{kw}$ & 5857691618,09 \\
\hline $20102 k w$ & 5919590 437,59 \\
\hline $20103 k w$ & 5819521390,53 \\
\hline $20104 \mathrm{kw}$ & 5561001 100,10 \\
\hline $20111 \mathrm{kw}$ & 6470384446,03 \\
\hline $20112 k w$ & 5083404023,41 \\
\hline $20113 k w$ & 2204758483,75 \\
\hline $20114 k w$ & 1993101 350,75 \\
\hline $20121 \mathrm{kw}$ & 2252255958,89 \\
\hline $20122 k w$ & 1806245906,33 \\
\hline $20123 k w$ & 2152219673,81 \\
\hline $20124 k w$ & 2199574 465,39 \\
\hline $20131 \mathrm{kw}$ & 2526537335,43 \\
\hline $20132 k w$ & 2224143903,09 \\
\hline $20133 \mathrm{kw}$ & 3998470552,14 \\
\hline $20134 \mathrm{kw}$ & 2305226862,00 \\
\hline $20141 \mathrm{kw}$ & 3175623838,23 \\
\hline $20142 k w$ & 2893973024,67 \\
\hline $20143 \mathrm{kw}$ & 1512865 180,84 \\
\hline $20144 k w$ & 742846634,90 \\
\hline $20151 \mathrm{kw}$ & 817491744,68 \\
\hline
\end{tabular}

Źródło: opracowanie własne na podstawie „Biuletynów Kwartalnych KNF - Rynek OFE”

W pierwszym kwartale 2015 r. wśród osób w wieku 18-20 lat liczba członków OFE spadła prawie o 75 tys. z prawie 224 tys. do niecałych 150 tys. osób. W tym samym kwartale wśród osób w wieku 21-25 lat liczba członków spadła o prawie 315 tys. z ponad 1,5 $\mathrm{mln}$ do 1,2 mln członków. Niewielki napływ nowych klientów do OFE z systematycznym odpływem najstarszych członków OFE, spowodowanym osiąganiem przez nich wieku 
emerytalnego, już obecnie prowadzi do spadku całkowitej liczby klientów OFE (tab. 3).

Całkowita liczba klientów OFE osiągnęła maksimum w marcu 2014, osiągając poziom 16703761 członków. Od tego momentu notowany jest systematyczny spadek liczby klientów OFE. Od marca 2014 roku do sierpnia 2014 liczba ta zmniejszyła się o prawie 136 tys., do poziomu 16567915 osób. Spadek liczby członków OFE ma negatywny wpływ na wysokość środków trafiających do OFE. Ale największy wpływ na ten spadek ma fakt, że dotychczasowi członkowie OFE zostali zobowiązani do złożenia deklaracji o dalszym przekazywaniu składek do swoich otwartych funduszy emerytalnych. Zgodnie z art. 11 ustawy nowelizującej z 2013 r. w okresie od 1 kwietnia do 31 lipca 2014 roku każdy członek OFE miał możliwość złożenia do ZUS oświadczenia woli o przekazywaniu części składki emerytalnej do OFE po 1 lipca 2014 roku. Od tej decyzji ubezpieczonego zależy, czy drugofilarowa składka jest dzielona na dwie części, między subkonto $w$ ZUS (4,38\%) oraz konto w OFE $(2,92 \%)^{2}$, czy też w całości trafia ona do ZUS i jest zapisywana na indywidualnym subkoncie ubezpieczonego. Należy podkreślić, że osoby, które nie złożyły oświadczenia o przekazywaniu części składki do otwartego funduszu emerytalnego, nadal pozostają członkami OFE, a fundusze zarządzają ich aktywami zgromadzonymi przed 1 lipca 2014 roku i dlatego ogólna liczba członków OFE nie uległa istotnej zmianie, mimo głębokich zmian wprowadzonych w 2014 roku (KNF 2015: 9). Począwszy od 2016 r., co 4 lata, w okresie od 1 kwietnia do 31 lipca każdy członek OFE będzie miał możliwość złożenia do ZUS takiego oświadczenia woli o przekazywaniu

\footnotetext{
2 Decyzję o podziale składki ubezpieczony może zmieniać raz na cztery lata. Wyjątkowo raz na dwa lata, tj. w 2014 i 2016.
}

części składki emerytalnej do OFE po 1 lipca danego roku (art. 39a ust. 1 ustawy o s.u.s.).

Według stanu na koniec marca 2015 roku zaledwie 15,1\% członków OFE złożyło oświadczenie o dalszym przekazywaniu części składki emerytalnej do OFE. Stanowi to około 2,5 mln osób. Warto dodać, że prawa do dalszego wnoszenia składek do OFE pozbawieni są najstarsi członkowie OFE. Składki ubezpieczonych, którzy osiągnęli wiek niższy niż 10 lat przed wiekiem emerytalnym, automatycznie kierowane są tylko na subkonto w ZUS (art. 22 ust. $3 \mathrm{w}$ związku z art. 22 ust. 3d ustawy o s.u.s.).

Zgodnie z przewidywaniami (Chybalski 2013: 11-22) rozbicie i obniżenie składki OFE, automatyczne zaprzestawanie odprowadzania składek najstarszych członków do OFE, spadająca liczba członków OFE oraz nieznaczna liczba członków, którzy zadeklarowali dalsze wnoszenie składki do OFE ma bezpośrednie przełożenie na liczbę składek odprowadzanych do otwartych funduszy emerytalnych (tab. 4) i w konsekwencji wielkość aktywów netto tych funduszy (tab. 5).

Jest to początek powolnego spadku wielkości aktywów netto otwartych funduszy emerytalnych $w$ nadchodzącej przyszłości. Przed 2014 r. OFE dysponowały aktywami netto o wartości nawet ponad $300 \mathrm{mld}$ zł. Po raz pierwszy wartość aktywów netto OFE przekroczyła 300 mld w dniu 15 października 2013 roku, a historyczne maksimum odnotowano 25 listopada 2013 roku, kiedy w bilansach funduszy wykazano w tej pozycji 307 mld zł.

\section{Transfer środków z OFE do ZUS}

Słaba konkurencja na rynku otwartych funduszy emerytalnych (Marcinkiewicz 2013: 184), bariery instytucjonalne (Chybalski 2009a: 26-41), niezadowalające wyniki inwestycyjne OFE (Dybał 2009) oraz narastający 
niedobór w Funduszu Ubezpieczeń Społecznych zdecydowały o konieczności przeprowadzenia zasadniczej reformy OFE w 2014 r. (Dybał 2014a). Jej kluczowymi elementami było obniżenie składki trafiającej do OFE, przeniesienie wyrażonych obligacyjnymi zobowiązaniami Skarbu Państwa części uprawnień emerytalnych ubezpieczonych z OFE do ZUS oraz liberalizacja zasad polityki inwestycyjnej OFE (Dybał 2014b).

Zgodnie $z$ art. 23 ustawy nowelizującej z 2013 r. 3 lutego 2014 r. nastąpił transfer 51,5\% aktywów OFE do ZUS. Całkowita wartość przenoszonych aktywów OFE wynosiła 153,1 mld zł. Wartość nominalna przekazanych do ZUS papierów wartościowych wyniosła łącznie 146 mld zł, z czego:

- 130,2 mld zł stanowiły skarbowe papiery wartościowe;

- 15,6 mld zł stanowiły obligacje emitowane przez Bank Gospodarstwa Krajowego na zasadach określonych w ustawie o autostradach płatnych oraz o Krajowym Funduszu Drogowym, gwarantowane przez Skarb Państwa (Dz. U. z 2015, poz. 641);

- 0,3 mld zł stanowity inne papiery wartościowe opiewające na świadczenia pieniężne, gwarantowane przez Skarb Państwa.

Ponadto otwarte fundusze emerytalne przekazały również do ZUS środki pieniężne o wartości 1,9 mld zł. Przy czym skarbowe papiery wartościowe przeniesione $w$ ten sposób do ZUS zostały z kolei nabyte przez ministra finansów, reprezentującego Skarb Państwa. Umożliwiło to ich umorzenie. Pozostałe aktywa przekazane zostały do Funduszu Rezerwy Demograficznej (Banaszczak-Soroka 2014).

\section{„Suwak bezpieczeństwa”}

Kolejnym elementem, który prowadzi do zwiększonego odpływu środków z otwartych funduszy emerytalnych, jest zastosowanie tzw. suwaka bezpieczeństwa.

Do listopada 2014 roku środki zgromadzone i trzymane na rachunku członka OFE, obok środków zapisanych na subkoncie, były wykorzystywane do wyliczania i wypłacania okresowej emerytury kapitałowej (art. 24 w zw. z art. 27 ustawy o emeryturach kapitałowych $w$ brzmieniu przed 1 lutego 2014) (Dz. U. z 2014 r., poz. 1097). Reforma drugiego filaru ubezpieczenia emerytalnego z 2014 roku, a konkretnie art. 5 pkt. 10 ustawy nowelizującej z 2013, wprowadziła stopniowe przenoszenie środków zgromadzonych na rachunku członka OFE na subkonto w ZUS, wraz ze zbliżaniem się członka OFE do wieku emerytalnego. Celem jest ochrona ubezpieczonego przed „ryzykiem złej daty". Zakończenie wnoszenia składek do OFE oraz stopniowe przenoszenie kapitału emerytalnego, $\mathrm{w}$ formie rat przez 10 lat przed osiągnięciem wieku emerytalnego, określane jest jako suwak bezpieczeństwa. $W$ ten sposób subkonto w ZUS stało się mechanizmem ochrony kapitału emerytalnego przed ryzykiem spadku wartości w ostatnich latach aktywności zawodowej członka OFE (Jakubowski 2014). Dlatego obecnie tylko środki zapisane na subkoncie są wykorzystywane do wyliczenia okresowej emerytury kapitałowej (art. 24 ustawy o emeryturach kapitałowych).

Zgodnie z art. 13 ustawy nowelizującej z 2013 roku, pierwsze przekazanie środków w ramach suwaka bezpieczeństwa nastąpiło do dnia 12 listopada 2014 roku i obejmowało okres od 1 lutego do 30 października 2014 roku. Łącznie OFE przekazały wówczas do ZUS kwotę 3,7 mld zł. Ten transfer środków z OFE do ZUS był jeszcze znacząco mniejszy niż składka przekazana przez ZUS do OFE. Ale już w I kwartale 2015 roku OFE przekazały $w$ ramach suwaka ponad 1 mld zł (KNF 2015), co stanowiło więcej niż kwota składek 
Tabela 5. Aktywa netto OFE (PLN)

\begin{tabular}{|c|c|}
\hline Data & Aktywa netto OFE (PLN) \\
\hline 1999 & 2254837873,51 \\
\hline 2000 & 9921249691,37 \\
\hline 2001 & 19409420713,11 \\
\hline 2002 & 31564646 669,65 \\
\hline 2003 & 44833088918,58 \\
\hline 2004 & 62626944016,05 \\
\hline 2005 & 86078777334,35 \\
\hline 2006 & 116563259565,10 \\
\hline X 2007 & 142800986642,69 \\
\hline 2007 & 140030893475,80 \\
\hline 2008 & 138261447317,79 \\
\hline II 2009 & 130867800968,77 \\
\hline 2009 & 178630090689,18 \\
\hline 2010 & 221251119982,00 \\
\hline 2011 & 224701817601,76 \\
\hline 2012 & 269596467329,15 \\
\hline 2013 & 299272473053,74 \\
\hline II 2014 & 153963070937,18 \\
\hline 2014 & 148450552223,89 \\
\hline III 2015 & 155220056544,18 \\
\hline VI 2015 & 153721914 609,98 \\
\hline
\end{tabular}

Źródło: opracowanie własne na podstawie „Biuletynów Miesięcznych KNF - Rynek OFE”.

przekazanych z ZUS do OFE w tym samym okresie $(0,82 \mathrm{mld} z \nmid)$.

\section{Nieformalne wygaszanie kapitałowej części ubezpieczenia emerytalnego}

Reforma drugiego filaru systemu emerytalnego fundamentalnie zmieniła wielkość aktywów OFE, co obrazuje tabela 5. Jednocześnie zmiany wprowadzone w 2014 r. rozpoczęły proces powolnego spadku wielkości aktywów netto OFE, oznaczający stopniowe i nieformalne wygaszanie kapitałowej części ubezpieczenia emerytalnego.
Zmiany te są na tyle duże, że będą miały wpływ na adekwatność krajowego reżimu emerytalnego w długim okresie (Chybalski 2011: 2-4).

Od początku drugiego kwartału 2015 roku można obserwować systematyczny spadek wielkości aktywów netto otwartych funduszy emerytalnych, który jest dodatkowo pogłębiany przez korektę na krajowym rynku giełdowym. Decydujące znaczenie dla dalszego funkcjonowania rynku otwartych funduszy emerytalnych w Polsce będzie mieć orzeczenie Trybunału Konstytucyjnego. Ustawa nowelizująca z 2013 
r. stała się przedmiotem dwóch skarg. Pierwszą złożył prezydent Bronisław Komorowski, który podaje w wątpliwość legalność przepisów związanych z zakazem inwestowania OFE w obligacje i nakazem tymczasowego inwestowania OFE w akcje. Jednocześnie prezydent wskazuje na niekonstytucyjność zakazu reklamy OFE w okresie składania do ZUS oświadczeń woli członków OFE o dalszym przekazywaniu części składki emerytalnej do OFE (Wniosek Prezydenta Rzeczypospolitej Polskiej 2014). Drugą skargę do Trybunału Konstytucyjnego złożyła Rzecznik Praw Obywatelskich, prof. Irena Lipowicz. Wskazała ona, że art. 11 ust. 1 i 2 ustawy nowelizującej z 2013 r., nakazujący transfer części środków z OFE do ZUS w odniesieniu do ubezpieczonych urodzonych między 31 grudnia $1948 \mathrm{r}$. a 1 stycznia 1968 r., którzy dobrowolnie stali się członkami OFE, pozostaje w kolizji z konstytucyjną zasadą ochrony zaufania do państwa i prawa oraz stanowi nieproporcjonalne ograniczenie zasady wolności człowieka (Wniosek Rzecznika Praw Obywatelskich 2014).

Orzeczenie Trybunału Konstytucyjnego będzie miało duże konsekwencje dla stabilności finansów publicznych. Minister Pracy i Polityki Społecznej szacuje, że zakwestionowanie całej reformy emerytalnej z 2013 r. spowoduje wzrost państwowego długu publicznego o 152,3 mld zł (wg metodologii polskiej) oraz długu sektora instytucji rządowych i samorządowych (o 164 mld zł wg metodologii UE) (Opinia Ministra Pracy i Polityki Społecznej 2014). Jednocześnie nastąpiłoby pogłębienie deficytu w Funduszu Ubezpieczeń Społecznych. Tylko w 2014 r. na wypłaty świadczeń potrzebne byłoby dodatkowe 14,7 mld zł.

Nie należy spodziewać się aż tak radykalnego orzeczenia ze strony Trybunału Konstytucyjnego. Natomiast można przypuszczać, że zostanie zakwestionowany zakaz reklamy OFE w okresie podejmowania decyzji przez członków OFE o dalszym wnoszeniu składek do funduszu emerytalnego. Już tylko ta zmiana powinna umożliwić zahamowanie spadku liczby członków OFE oraz utrzymanie napływu składek do otwartych funduszy emerytalnych na dotychczasowym poziomie ${ }^{3}$.

\section{Zakończenie}

Do roku 2007 nie nagłaśniano krytycznych uwag do obowiązującego systemu emerytalnego. Dopiero światowy kryzys finansowy obnażył znaczne ułomności systemu i wywołał ostrą polemikę naukowców, polityków i praktyków. Część z nich dowodziła, że obowiązujący system emerytalny jest skonstruowany prawidłowo, wymaga jedynie drobnych korekt. Inni wyrażali skrajny pogląd całkowitej likwidacji kapitałowego filaru systemu emerytalnego, tj. otwartych funduszy emerytalnych.

W konsekwencji rząd, analizując funkcjonowanie systemu emerytalnego, także w kontekście bezpieczeństwa finansów państwa, a tym samym przyszłych emerytów, zdecydował o głębokich zmianach w konstrukcji i parametrach systemu emerytalnego w latach 2011-2014. Do najważniejszych należy zaliczyć: obniżenie składki trafiającej do otwartych funduszy emerytalnych i wykreowanie subkonta w ZUS, zniesienie obowiązku dalszego opłacania składki trafiającej do OFE, transfer ponad 50\% środków zgromadzonych w OFE do ZUS, zastosowanie tzw. suwaka bezpieczeństwa oraz wprowadzenie zakazu akwizycji

\footnotetext{
${ }^{3}$ Szerzej na temat wpływu zmian legislacyjnych w krajach Europy Srodkowej i Wschodniej na liczbę członków funduszy emerytalnych oraz ilość i wielkość składek emerytalnych trafiających do kapitałowych części systemów emerytalnych patrz: F. Chybalski, Liberalization of pension systems in Central and Eastern Europe (Chybalski 2009b: 6-25).
} 
i reklamy na rzecz OFE. Jak wykazano w niniejszej analizie, zmiany te powoli i stopniowo prowadzą do nieformalnego wygaszania kapitałowej części ubezpieczenia emerytalnego.

Wprowadzenie dobrowolności członkostwa w OFE dla najmłodszych ubezpieczonych, którzy dopiero wkraczają na rynek pracy, połączone z wygaszaniem członkostwa w OFE najstarszych ubezpieczonych w związku z osiąganiem przez nich wieku emerytalnego, już obecnie prowadzi do spadku całkowitej liczby klientów OFE. To oznacza spadek liczby i wysokości składek przekazywanych przez ZUS do OFE. Spadek ten jest tym bardziej pogłębiony, że obecni członkowie OFE muszą złożyć oświadczenie woli do ZUS o dalszym opłacaniu składek na otwarte fundusze emerytalne. Od tej decyzji ubezpieczonego zależy, czy składka na drugi filar ubezpieczenia emerytalnego będzie trafiała do OFE $(2,92 \%$ podstawy wymiaru) i na subkonto w ZUS (4,38\% podstawy wymiaru), czy też w całości na subkonto w ZUS (7,3\% podstawy wymiaru). Według stanu na koniec marca 2015 r. zaledwie 15\% członków OFE złożyło oświadczenie o dalszym przekazywaniu części składki emerytalnej do OFE.

\section{Bibliografia}

Antonów K. (2011), OFE - ubezpieczenie versus oszczędzanie, [w:] Wspótczesne problemy prawa pracy i ubezpieczeń społecznych, red. Ludwik Florek, Łukasz Pisarczyk, Warszawa.

Banaszczak-Soroka U. (2014), Rynki finansowe, Warszawa.

Chybalski F. (2009a), Barriers to increased effectiveness of investment by Open Pension Funds in Poland, [w:] Funded part of Polish Pension System. Selected Problems, red. F. Chybalski, Łódź.
Wszystkie te zmiany spowodowały znaczny spadek liczby i kwoty składek przekazywanych do otwartych funduszy emerytalnych, który utrzymuje się od 2011 roku. Wielkość tego spadku najlepiej obrazuje zestawienie kwoty środków przekazanych $\mathrm{w}$ pierwszym kwartale 2011 roku (6 $470 \mathrm{mln}$ PLN) z kwotą przekazaną przez ZUS w pierwszym kwartale 2015 roku $(817 \mathrm{mln}$ PLN). Spadająca liczba członków OFE wraz z coraz mniejszymi wpływami do otwartych funduszy emerytalnych z tytułu składek skutkuje powolnym zmniejszaniem się łącznych aktywów netto OFE, które i tak doznały poważnego uszczerbku 3 lutego 2014 r. w momencie transferu z OFE do ZUS aż 153 151,2 mln PLN.

Dlatego też decydujące znaczenie dla dalszego rozwoju rynku otwartych funduszy emerytalnych oraz zahamowania procesu nieformalnego wygaszania kapitałowej części ubezpieczenia emerytalnego będzie miał wyrok Trybunału Konstytucyjnego. Szczególne znaczenie będzie miała ta część, która będzie dotyczyć zakazu reklamy OFE w okresie składania oświadczeń woli ubezpieczonych o dalszym przekazywaniu części składki emerytalnej do OFE.

Chybalski F. (2009b), Liberalization of pension systems in Central and Eastern Europe, [w:] Funded part of Polish Pension System. Selected Problems, red. F. Chybalski, Łódź.

Chybalski F. (2011), Adekwatność systemów emerytalnych według celów OMC a rezimy emerytalne w Europie, „Polityka Społeczna”, numer specjalny, cz. 1.

Chybalski F. (2013), Dobrowolność przynależności do OFE a dywersyfikacja ryzyka $w$ systemie emerytalnym 
w Polsce, [w:] Chybalski F., Marcinkiewicz E., Współczesne zabezpieczenie emerytalne, Łódź.

Dybał M. (2009), Uwarunkowania działalności inwestycyjnej OFE, [w:] Otwarte fundusze emerytalne $w$ Polsce. Analiza działalności inwestycyjnej, finansów oraz decyzji członków, red. F. Chybalski, Warszawa.

Dybał M. (2014a), Wpływ otwartych funduszy emerytalnych na deficyt budżetowy i dług publiczny, [w:] Miemiec W., Sawicka K., Instytucje prawnofinansowe w warunkach kryzysu gospodarczego, Warszawa.

Dybat M. (2014b), The Financial Crisis and the Polish Open Pension Funds System, "Socialiniai Tyrimai - Social Research", nr 2.

Jakubowski S. (2014), Otwarte fundusze emerytalne typu B jako mechanizm ochrony kapitału emerytalnego $w$ ostatnich latach aktywności zawodowej członka otwartego funduszu emerytalnego, [w:] Miemiec W., Sawicka K., Instytucje prawnofinansowe w warunkach kryzysu gospodarczego, Warszawa.

Klimkiewicz A. (2013), Gromadzenie kapitału emerytalnego w ZUS i OFE jako element warunkujqcy wysokość emerytury, [w:] Współczesne zabezpieczenie emerytalne. Wybrane aspekty ekonomiczne, finansowe i demograficzne, pod red. F. Chybalskiego, E. Marcinkiewicz, Łódź.

Marcinkiewicz E. (2013), Efektywność finansowa powszechnych towarzystw emerytalnych, [w:] Chybalski F., Marcinkiewicz E., Współczesne zabezpieczenie emerytalne, Łódź.

Marcinkiewicz E., Zmiana zasad dystrybucji składki emerytalnej a znaczenie
OFE na rynku finansowym, „Polityka Społeczna”, numer specjalny, cz 1.

Opinia Ministra Pracy i Polityki Społecznej z dnia 4 marca 2014 w sprawie wniosku Prezydenta Rzeczypospolitej Polskiej z dnia 30 stycznia $2014 \mathrm{r}$. o zbadanie zgodności z Konstytucją RP niektórych przepisów ustawy z dnia 6 grudnia 2013 r. o zmianie niektórych ustaw w związku z określeniem zasad wypłaty emerytur ze środków zgromadzonych $w$ otwartych funduszach emerytalnych.

Pacud R. (2012), Zmiana kierunku reformy emerytalnej z 1999 r., „Państwo i Prawo", nr 1.

Rynek otwartych funduszy emerytalnych w I kwartale 2015 r., Urząd Komisji Nadzoru Finansowego, Warszawa.

Wniosek Prezydenta Rzeczypospolitej Polskiej z dnia 30 stycznia 2014 r. (sygn. akt K 1/14) o zbadanie zgodności z Konstytucją RP niektórych przepisów ustawy z dnia 6 grudnia 2013 r. o zmianie niektórych ustaw w związku z określeniem zasad wypłaty emerytur ze środków zgromadzonych w otwartych funduszach emerytalnych (Dz. U. poz. 1717).

Wniosek Rzecznika Praw Obywatelskich z dnia 29 sierpnia 2014 r. (sygn. akt $K 1 / 14$ ) o zbadanie zgodności z Konstytucją RP niektórych przepisów ustawy z dnia 6 grudnia 2013 r. o zmianie niektórych ustaw w związku z określeniem zasad wypłaty emerytur ze środków zgromadzonych w otwartych funduszach emerytalnych (Dz. U. poz. 1717).

Zawieja-Żurowska K. (2013), Refleksja nad przyszłościq systemu emerytalnego oraz finansowego bezpieczeństwa jego beneficjentów, [we:] Współczesne zabezpieczenie emerytalne. Wybrane aspekty ekonomiczne, finansowe 
i demograficzne, pod red. F. Chybalskiego, E. Marcinkiewicz, Łódź.

Źródła prawa

Ustawa z dnia 27 października 1994 r. o autostradach płatnych oraz o Krajowym Funduszu Drogowym, tekst jedn., Dz. U. z 2015, poz. 641.

(Ustawa s.u.s) Ustawa z dnia 13 października 1998 r. o systemie ubezpieczeń społecznych, tekst jedn. Dz. U. z 2009 r., nr 205, poz. 1585 ze zm.

Ustawa z dnia 21 listopada 2008 r. o emeryturach kapitałowych, tekst jedn. Dz. U. z 2014 r., poz. 1097.
(Ustawa nowelizująca z 2011 r.) Ustawa $z$ dnia 25 marca 2011 r. o zmianie niektórych ustaw związanych z funkcjonowaniem systemu ubezpieczeń społecznych, Dz. U. z 2011 r., nr 75, poz. 398 , ze zm.

(Ustawa nowelizująca z 2013 r.) Ustawa z dnia 6 grudnia 2013 r. o zmianie niektórych ustaw w związku z określeniem zasad wypłaty emerytur ze środków zgromadzonych w otwartych funduszach emerytalnych, Dz. U. z 2013 r., poz. 1717.

\title{
Phasing-out of the Funded Part of Pension System in Poland
}

\begin{abstract}
The paper discusses the effects of the pension reform of 2014 for the funded part of pension system in Poland. The analysis focuses on the effects of reduction of contributions paid to pension funds, the introduction of freedom to pay these contributions and the implications of transfers of capital from open pension funds to Social Security Institution. The main thesis of this article is: changes introduced in 2014 lead to phasing-out of the capital part of the pension insurance in Poland. A decisive factor for the further development of the open pension fund market will be a judgment of Constitutional Tribunal in 2016. Methodology used in the research: economic analysis of law.
\end{abstract}

Keywords: OFE, pension fund, second pillar, pension system, pension insurance. JEL: J32, J26 